\title{
The No Disadvantage Test: Failing Workers
}

\section{Peter Waring and John Lewer ${ }^{1}$}

\section{Abstract}

A decade since the introduction of enterprise bargaining in the federal jurisdiction provides a timely opportunity to critically review the evolution and operation of 'the no disadvantage test'. The successor to the 'public interest test', the mechanism has remained fundamental to regulators' assurances that workers, on the whole, would be 'no worse off' under enterprise bargaining. This paper however, contends that the test has evolved to the point where it is a far weaker benchmark measure than originally conceived. Examining legislative changes over the last ten years and drawing on case law, the authors argue the no disadvantage test has frayed to the extent that it is unable to safeguard workers' interests under a decentralised wages system. The authors posit the no disadvantage test must be reconstructed if the original intent of the test is to be preserved, and pose a number of alternative strategies to reinstate a genuine and fail safe mechanism to protect workers' wages and conditions.

\section{Introduction}

In the uncertain journey to embrace more individualised, decentralised forms of bargaining, and perhaps unlike the free-market visions of those in other economies (such as New Zealand), Australian governments have been breathless in their rhetoric that a shift from centralised awards would not be achieved through workers' disadvantage. At the kernel of the change would be an effective safety net protecting and maintaining workers' conditions. The Australian Labor Party's policy in the mid-1990s sought to maintain the 'national award system that protects workers (particularly those with little bargaining power) from exploitation, (and) guarantees a fair safety net that underpins enterprise bargaining' (Alexander and Lewer, 1996: 112). The Coalition parties promised to 'maintain the current award system, overseen by the Australian Industrial Relations Commission . . . [which] will continue to deliver safety net increases to the lowest paid . . . establish minimum conditions for agreements to ensure adequate protection, especially for the low paid' (Alexander and Lewer, 1996: 112-113). Much of this legislative intent was subsequently manifest as the no disadvantage test (NDT), a statutory device which, 
aligned with the concept of the public interest, sought to ensure that no worker would be worse off under enterprise bargaining. As this paper argues, the NDT became a symbol of civility in the Australian industrial relations system - a means to convince workers that equity considerations would not be forgotten in the new decentralised system.

There may be some debate as to whether the NDT, as it was introduced in 1992, was merely a symbol ${ }^{2}$ rather than an effective means of eliminating the possibility of workers being disadvantaged through enterprise bargaining. Clearly, there is considerable tension between promoting bargaining to employers on the one hand, whilst persuading workers that the NDT would safeguard their interests in bargaining. However, whilst the capacity of the original NDT to protect workers is a moot point, we would argue that there is significant evidence that the NDT has weakened markedly since its introduction. The steady erosion of the NDT over the last decade, has also been observed by O'Neill (1997), Naughton (1997), and Merlo (2000). In this paper, we draw together these observations and evaluate a number of alternative mechanisms to either reconstruct or replace the NDT.

The paper firstly traces the legislative evolution of the no disadvantage test (NDT), arguing that changes in the regulatory framework have resulted in a dilution of the NDT's capacity to maintain immutable minimum benchmarks. Secondly, it is argued that the outwardly loose compliance procedures and the complexities associated with the actual application of the test increase the possibility of the NDT failing to protect the interests of workers. Furthermore, whilst more definitive evidence is needed, the weakening of the NDT appears to have been exacerbated through both award simplification and the growing disparity between award wages and agreement outcomes. Other eyidence suggests the erosion of the award bulwark provides tactical opportunities for employers to further their claims at enterprise bargaining. Finally, we evaluate four proposals for protecting workers' wages and conditions in the decentralised Australian industrial relations system.

\section{The Evolution Of The Test}

Since the introduction of formalised enterprise bargaining in October 1991, the changing tribunal and legislative tests established to safeguard the interests of workers have paralleled the evolving changes in the shift to an increasingly decentralised wages system. Analysis of the test's legislative history and its application by the tribunals (see Appendix A), suggests that each of these changes has resulted in a weakening of the safeguard despite the intention to ensure workers were not disadvantaged through enterprise bargaining. Initially, it seemed that the public interest test, and the original NDT, were designed to promote bargaining outcomes consistent with productivity enhancement, but more recent incarnations of the NDT now appear to also permit labour cost minimisation and reduction.

Under section 115 of the Industrial Relations Act, 1988 (IRA) parties to a dispute were permitted to draft a memorandum of terms for the settlement of the dispute and seek certification of that agreement by the Australian Industrial Relations Commission (AIRC). 
The Commission was obliged to certify the agreement, subject to it forming the belief that the agreement was in the interests of the parties and that it was not contrary to the public interest. As a result of the strict application of the test by the AIRC, few agreements were certified. The AIRC's perhaps parsimonious approach to this 'new' bargaining stream led Creighton and Stewart (1990:70) to conclude 'The Commission's initial attitude appears to have been one of extreme reluctance to countenance their use in any but the most exceptional circumstances'.

The next opportunity to apply an NDT-styled enterprise bargaining benchmark arose with, as Dabscheck (1995:73) observed, the AIRC's begrudging endorsement of enterprise bargaining in the October 1991 national wage case. The decision of the AIRC permitted enterprise bargaining agreements provided any such agreement met the requirements of the structural efficiency principle and did not involve a reduction in ordinary time earnings or depart from the Commission's standards. However, especially in the opinion of the Australian Council of Trade Unions (ACTU) and the federal government, the AIRC's arrangements were viewed as unduly restrictive and would do little to facilitate enterprise bargaining (EB). To circumvent the Commission's limited willingness to endorse a relatively unfettered model of enterprise bargaining, the Labor government introduced legislation into the federal Parliament which, when ultimately enacted as the Industrial Relations Amendment Act, 1992 (IRAA) established, inter alia a different legislative test for the certification of enterprise agreements. This benchmark, described as the "no disadvantage test', empowered the Commission to certify agreements provided none of the terms and conditions of the proposed agreement proved to be less advantageous than any of the conditions contained in the relevant award or law. Additionally, the 1992 amendments gave the Commission an important discretionary power to approve agreements that did contain disadvantage as defined by the Act provided the agreement was not contrary to the public interest. Plainly, the 1992 amendments purposefully weakened the test embodied in the 1991 EB Principle. Finally, the then President of the AIRC, Mr Justice Maddern strongly criticised the shift in the benchmark standard and warned that matters could now be included in agreements and be certified without prior scrutiny of the tribunal and without reference to public interest considerations (Dabscheck, 1995:75).

Subsequent legislation by the Keating Government, the Industrial Relations Reform Act, 1993 (IRRA), retained in section $170 \mathrm{NC}(2)$ the earlier 'no disadvantage test' but significantly changed how disadvantage would be 'calculated'. In his second reading speech, the Minister argued for a broader balancing of the benefits and reductions in assessing the ccrtifiability of any proposed agreement:

In the bargaining process employees want and deserve the security of knowing they cannot be worse off - worse off in totality. The security of knowing that the conditions they currently enjoy are not to be traded off without something being offered in return. It may not always be a pay rise, it may be cxtra training, more flexible rosters or just greater security; it will be something nevertheless. (House of Representatives Hansard, 28 October 1993 at p. 2778) 
Also, sections $170 \mathrm{MC}(6)$ and $170 \mathrm{NC}$ (3) (for Enterprise Flexibility Agreements) of the IRRA, altered the definition of an award to exclude (a) an order under Part VIA or (b) a certified agreement or (an enterprise flexibility agreement [EFA]). This effectively meant that the NDT could not be applied against a certified agreement or EFA but rather against the award safety net. This subtle change may not have had a dramatic impact on the industrial relations landscape of 1994, when the Act was introduced. However, over time, as we will argue later, growing disparity between award wages and wages outcomes in certified agreements meant that this new NDT constituted a far weaker test than that provided by the 1992 amendments.

How the NDT was to be applied was decided by a Full Bench of the AIRC in the 1995 Enterprise Flexibility Agreement Test Case. It determined that the NDT was not to be regarded as a line by line test (as operated under the 1992 act) but rather as a global measure, assessing on an overall basis the employment conditions of proposed agreements against relevant awards. Specifically, the Commission found (pp. 45-46):

Where the implementation of an agreement would result in a reduction in employee entitlements or protections the Commission must determine whether, in the context of the terms and conditions of employees concerned when considered as a whole, the reduction would be contrary to the public interest. We agree with the submission put by $\mathrm{ACCl}$ in this regard, that is the Commission should adopt a global approach rather than a line by line approach in making a public interest determination under section $170 \mathrm{NC}(2)(\mathrm{b})$. In practice this involves a consideration of the overall package of terms and conditions of employment to apply to the employees covered by the agreement. The reductions in cmployee entitlements and protections need to be balanced against the benefits provided in the agreement. Given the need to balance a range of factors the determination of whether or not the no disadvantage test has been met in a particular case will largely be a matter for the impression and judgement of the Commission member at first instance....

Even if the overall package of terms and conditions of employment would result in a net reduction of protections or entitlements, the Commission may nevertheless determine such a reduction was not contrary to the public interest. For example, such a conclusion may be reached where the reductions are necessary as part of a strategy for dealing with a short-term business crisis and revival.

The widely reported Tweed Valley Fruit Processors Case (1995) closely examined, inter alia an interpretation of section 170NC of the IRRA, firstly by Commissioner Redmond of the AIRC, then on appeal by a Full Bench of the Commission and ultimately on further appeal to a Full Court of the Industrial Relations Court of Australia. The case reinforced the principle that in the application of the no disadvantage test, the AIRC must give substantial weight to consideration of the public interest. Specifically, it was held (on appeal) that the proposed agreement failed the NDT by seeking to 'buy-out' some award sick leave entitlements. Both appellant jurisdictions believed the Commissioner had misconceived the nature of the test by not adequately recognising the public interest 
requirement to protect well-established and accepted community standards, including test case decisions. An entitlement to sick leave was found to be a community standard traceable back to 1922. No agreement could be approved 'unless and until' the public interest issue had been addressed. The extent of the litigation, and the finding of an overarching implied right to community standards (outside any agreement of the parties) strengthened this version of the NDT's capacity to resist downward flexibility in wages and conditions, at least those perceived as community standards.

The Workplace Relations Act, 1996 (WR Act) retained the prevailing no disadvantage test. The Labor Opposition and the minority parties in the Senate frustrated the legislative intention of the Howard Government to replace the NDT with a much diminished test relying on just seven minimum conditions ${ }^{3}$. Perhaps as an unintended outcome, the retention of awards as the benchmark for the NDT also lent some weight to John Howard's 1996 electoral catchery that 'no worker would be worse off' (see Williams, 1997:166).

The WR Act version of the no-disadvantage test, described by a Full Bench of the Commission (including the President) as 'quite clear'4, is set out in section 170XA of the Act. It relevantly provides:

170XA When does an agreement pass the no-disadvantage test?

(1) An agreement passes the no-disadvantage test if it does not disadvantage employees in relation to their terms and conditions of employment.

(2) Subject to sections $170 \mathrm{XB}, 170 \mathrm{XC}$ and $170 \mathrm{XD}$, an agreement disadvantages employees in relation to their terms and conditions only if its approval or certification would result, on balance, in a reduction of the overall terms and conditions of those employees under:

(a) relevant awards or designated awards; and

(b) any law of the Commonwealth, or of a State or Territory, that the Employment Advocate or the Commission (as the case may be) considers relevant.

Outwardly, little difference exists between the NDT contained in section 170XA of the WR Act 1996 and sections $170 \mathrm{MC}$ and $170 \mathrm{NC}$ of the preceding IRRA. Naughton (1997) however, argues that the statutory language of the WR Act places even more emphasis on the NDT being a global test rather than a line by line comparison, and hence, more closely resembles the decision in the Enterprise Flexibility Agreement Test Case. Naughton (1997:19) states that whereas the IRRA asks the AIRC to consider whether agreements involve a reduction of entitlements or protections under an award, the WR Act requires the AIRC to consider whether there is a reduction in the 'overall terms and conditions of employees' under an award. Commissioner Whelan acknowledged this slight difference in the implied meaning of the statutes in Bunnings Case. He held:

The major difference between the tests as enunciated in section $170 \mathrm{NC}(2)$ and section $170 \mathrm{XA}$ is that the contents of the agreement must be considered as a whole to determine if, on 
balance, it would result in a reduction in the overall terms and conditions of the employees concerned and only if such an overall reduction is found does consideration of the public interest apply.

Creighton and Stewart (2000:168) speculate that this minor legislative change may result in more 'trading off' and 'cashing out' of what used to be seen as socially desirable employment conditions such as parental leave. This possibility is strengthened by remarks made by the then Minister for Workplace Relations Peter Reith, in a speech delivered to the American Chamber of Commerce in May 1997. He explained:

The global (NDT) test means that any award or State legislative condition can be varied. There is no single condition that is not open to variation - every condition is open to variation to tailor it to the needs of the enterprise subject to the statutory minima.

These comments suggest that there are no 'sacred cows' and that the parties may alter all employment conditions. The likelihood of this occurring and gaining the imprimatur of the AIRC increases when one considers how the AIRC has interpreted its 'public interest' obligations under the WR Act. As discussed by Senior Deputy President Duncan in Australian Workplace Agreements 1997, the AIRC is to be guided by the objects of the WR Act when taking into account public interest considerations. The objects of the WR Act emphasise economic and efficiency objectives whilst describing awards as forming a safety net of minimum wages and conditions. Indeed, a number of agreements have been approved which have allowed the 'cashing-in' of annual leave (Silver Chain Registered Nurses Agreement, 1997), long service leave (Custom Publishing Pty Ltd South Australia Agreement, 1997) and accumulated sick leave (Greyhound Pioneer Australia Limited Certified Agreement, 1998) [Australian Labour Law Reporter: 56-140]. In a press release defending the practice of cashing-out provisions, Mr Reith said:

Provisions relating to annual leave and long service leave have a major impact on the availability of employees to undertake work tasks at any particular time and can create problems for management work planning. (Australian Labour Law Reporter: 56-140)

\section{The Approval Of 'Failed'Agreements}

The limited protection afforded by the no disadvantage test has been weakened further by the inclusion of discretionary provisions in the WR Act which enable the Commission to certify agreements even if they fail the no disadvantage test. Section 170LT(3) states that agreements may be taken to have passed the no disadvantage test provided (a) the only reason why the Commission must not certify an agreement is that the agreement does not pass the no disadvantage test; and (b) the Commission is satisfied that certifying the agreement is not contrary to the public interest. An example of such a situation is outlined in subclause (4) of section 170LT whereby the AIRC believes that an agreement, which has failed to pass NDT, is part of a reasonable strategy to deal with a short term 
business crisis or assist in the revival of a single business. These provisions are mirrored in Part VID where the Office of the Employment Advocate (OEA) is obliged to refer Australian Workplace Agreements (AWA) which it believes may not pass the NDT, to the AIRC for consideration (section 170VPC[3]). The AIRC, under section 170VPG(3) and section $170 \mathrm{VPG}(4)$, has similar responsibilities as under section 170LT (3) and (4).

According to the OEA website, approximately two per cent, just over 3,000, of all AWAs have been referred to the Commission. Around 1,039 of these, have been approved by the AIRC. This means that 1,963 AWAs have been refused by the AIRC. The figures presented in table 1 , indicate that 45 per cent of all AWAs referred by the OEA were approved by the AIRC, whilst 26 per cent were approved with undertakings. What remains unclear however, is how many AWAs have been approved by the AIRC, with respect to section 170LT(3) and whether the reasons given were similar to the example set out in section 170LT(4). Using the percentage figures provided in table 1 and the raw figures supplied by the OEA, we can at least submit that approximately 2,132 'suspect' AWAs have been approved by the AIRC. It may be that, in a proportion of these cases, the OEA's concerns were unfounded. However, it is more probable that these AWAs were passed with respect to section 170LT (3) - or in other words, these AWAs failed the NDT but were passed on public interest grounds.

Table 1: Awas Finalised By The AIRC, 1998 And 1999

\begin{tabular}{|l|c|}
\hline & $\begin{array}{c}\mathbf{1 9 9 8} \text { and } \mathbf{1 9 9 9} \\
\mathbf{\%}\end{array}$ \\
\hline Approved & 45 \\
\hline Approved with undertakings & 26 \\
\hline Refused & 11 \\
\hline Withdrawn & 18 \\
\hline All & 100 \\
\hline
\end{tabular}

Source: DEWRSB (2000) p.79.

In the first referral of AWAs under section 170VPB(3) to the AIRC, Senior Deputy President Duncan considered how the Commission should apply the 'public interest'. He found the AIRC had a broad discretionary power when considering the public interest but should be guided by the objects of the WR $\Lambda$ ct. Duncan however, also contended that the objects of the WR Act could be interpreted as either supporting or denying approval. In the end, Duncan was persuaded that the statutory example in section 170VPG (4) (the short-term business crisis) meant that he should approve the AWAs. In a similar case, DP Duncan approved an AWA which, although failing the NDT, (the OEA had calculated the employee would receive $\$ 7000$ p.a. less than the relevant award) was held to satisfy the 
public interest test. Although the employer's circumstances were not comparable with the statutory example of the short-term business crisis, Duncan found that this did not limit the grounds on which an AWA could be approved (Workplace Express: $31 / 5 / 01$ ). This difficulty in balancing the NDT against the public interest has been discussed by Merlo (2000:229-31), and was also commented on by Commissioner Simmons in Daviesway Pty Ltd Enterprise Agreement (1999) where he noted in obiter:

I must confess difficulty with the juxtaposition of the two concepts of (a) non-compliance with the no-disadvantage test and (b) the public interest... The two concepts can only be reconciled by accepting that the legislation presumes that compliance with what would otherwise be the requirements of an award or the law is consistent with the public interest, but that in relatively extreme circumstances non-compliance would also not be contrary to the public interest. (p. 3)

Finally, whilst each historical change of the NDT has had the effect of weakening the test, it is also insightful to examine the Howard government's proposed changes to the NDT. Although they failed to pass through the Senate, the so-called second wave reforms would have further altered the operation of the test. The Workplace Relations Amendment (More Jobs, Better Pay) Bill 1999 (MOJO Bill) intended to alter the procedures so that certified agreements would be lodged and registered with a 'workplace registry' without public hearing or tribunal scrutiny. Moreover, the MOJO Bill would have empowered the Employment Advocate to certify AWAs that had failed the NDT without prior referral of these agreements to the AIRC. Additionally, the MOJO Bill provided that AWAs would take effect from the date of the parties reaching agreement thereby operating on a general assumption that the AWAs had met the NDT. Although the MOJO Bill did not pass into law, the Bill should be seen in the context of a decade of evolutionary change to the NDT - a decade which has witnessed a significant weakening of the NDT.

\section{The Complexity Of Ensuring No Disadvantage}

Rules 47 and 48 of the AIRC specify that in lodging an application to Commission for certification of an agreement, the parties need to swear an accompanying statutory declaration. This attests, inter alia that certification would not lead to, on balance, a net reduction in the overall terms and conditions of employment of employees covered by the proposed agreement. As held in the Enterprise Flexibility Test Case (and discussed earlier), "the determination of whether or not the no disadvantage test has been met in a particular case will largely be a matter for the impression and judgement of the Commission member at first instance'. But as Naughton (1997) highlights, considerable onus rests with the parties to identify any disadvantage. This leaves the Commission with considerable discretion as to how closely it scrutinises the actual agreement in comparison to the relevant award.

Evidence also suggests, that the measurement of whether a worker would be worse off is not uncomplicated. For instance, the Senate Estimates Committee questioned the 
Limployment Advocate over a case of a maritime worker losing 'thousands of dollars in wages because the OEA wrongly calculated that his AWA passed the no disadvantage test' (Workplace Express: 22 February, 2001).

Issues of complexity, though, go beyond the calculus involved in simple award agreement comparisons. Commissioner Whelan's remarks in the Bunnings Case go to the heart of this complexity where he stated:

The no-disadvantage test has sometimes been described as a 'no net reduction' test implying that the determination of disadvantage can be conducted purely as a mathematical exercise. Entitlements can be 'bought out' provided the value of those entitlements is compensated for by the wage the employec takes home at the end of the week, fortnight, month or year.

The benefits of some award conditions, however, cannot be so easily calculated and compensated for in that way. Parental leave, for example, is unpaid leave. It is an allowable matter under section $89 \mathrm{~A}$ and one of the minimum terms and conditions of employment for Victorian employecs covered by Schedule 1 A of the Act. It is not inconceivable that an agreement may be reached between an employer and a union or group of employees that in effect 'buys out' parental leave as a condition of employment. How does this Commission put a buy out value on the right to parental leave as a condition of employment? Could any agreement that removed the right to parental leave be considered, on balance, not to result in a reduction in the overall terms and conditions of cmployment of those employees? Should the Commission consider the purpose of award provisions are not simply their financial value to the employee?

As discussed in the previous section, the phenomenon of cashing in or out certain conditions or rights only seems to be growing in incidence, without encountering significant opposition. Whelan's remarks suggest not only that the true value of these provisions is not properly accounted for but also that the purpose of these conditions in supporting wider, societal objectives is not considered.

\section{The Erosion Of Awards}

One underlying reason for the weakening of the NDT over the last decade has been the steady erosion of the award safety net. As previously explained, awards play a pivotal role in forming the benchmark against which the NDT is applied. This section argues that the reduction of award terms and conditions, via the award simplification process and the failure of all parties to properly maintain award wages and conditions has further reduced the effectiveness of the NDT.

\section{Award Simplification}

Consistent with the federal government's policy agenda to 'encourage' individual and collective bargaining, the WR Act required all federal awards to be 'simplified' from their often complex and diverse array of conditions into twenty allowable matters (see Appendix 
B). Awards would be limited to, for example, provisions dealing with rates of pay; annual leave and leave loadings; personal/carer's leave, public holidays; redundancy pay; dispute settling procedures; allowances and superannuation. Additionally, the AIRC had an overarching responsibility to ensure that simplified awards (within a caveat of having regard to fairness) did not prescribe work practices or procedures which would have the effect of restricting the efficient performance of work or hindering productivity.

The AIRC considered award simplification principles in the Hospitality Award Test Case decided in December 1997. It defined simplified awards as those "which provide minimum working arrangements encompassing entitlements to pay and conditions and reasonable protections for employees and employers. . . and which are suited to the efficient performance of work according to the needs of particular workplaces or enterprises'. The Commission did not define 'workplace efficiency and productivity' (items 49(7)(b) and (c) of the WR Act) but simply noted the criteria "have a number of characteristics similar to those identified in the structural efficiency reviews of the $1980 \mathrm{~s}$ and 1990s'. ${ }^{5}$ Reflecting the complexity of the process, by 28 February 2001, 642 awards had been 'simplified' with 913 still to be finalised (AIRC website at http://www.airc.gov.au).

Award simplification posed the twin difficulties for the labour movement of finding where existing conditions 'lost' through simplification could be relocated and estimating the implications of simplification on the NDT. Alexander and Lewer (1998: 231) noted that the "long-term value of the (NDT) test becomes questionable as awards move to become "safety nets"'. Likewise, Merlo (2000:224) has observed that award simplification results in a 'less relevant benchmark' for the NDT. Similarly, O'Neill (1997:13) has claimed:

It is helpful to ask what will be gained if award simplification proceeds, at least to a point where clauses are removed from awards, or nominated as being unenforceable. The main gain (for employers) will be that the bar for the no disadvantage test (NDT, as applies in the Act to various forms agreements) will be set lower, given that award provisions will be less. This will mean that in future enterprise bargaining rounds, it will be easier for an agreement to meet the NDT, and this is the main force behind employers' push to simplify awards.

The Coalition government's strategy was essentially built on the proposition that as awards were 'simplified', to maintain the spread and depth of conditions, unions and individuals would be encouraged (coerced?) into the bargaining streams. Theoretically, award simplification did threaten the extensive award system's capacity to protect workers' entitlements where the 'lost' conditions were not secured through alternative industrial instruments such as collective enterprise agreements. However, some anecdotal evidence shows that the coping strategies adopted by the parties, especially the use of creative arguments before the AIRC, may have led to the retention of many otherwise threatened employment conditions. The extent of this 'firewalling' though needs much more detailed data gathering. Without this full evidence, it is difficult to form definitive conclusions. Clearly the removal of some conditions has reduced the NDT 'hurdle', although the extent of this reduction varies across industries. 
Finally, it is has been argued that prior to the simplification process, the award system was seriously flawed. Essentially, this criticism turned on the incomplete coverage of the workforce by awards, considerable evidence of employers failing to comply with awards (with small penalties for non-compliance) and serious impediments to effective enforcement. McCallum (1994: 224) has argued the purpose of the award system as the 'pre-eminent mechanism for safeguarding the minimal rights of Australian employees' is severely constrained by these 'imperfections'. Given these impediments, it needs to be questioned whether the defects in the pre-cxisting award system warranted its use as the dominant mechanism underpinning the no-disadvantage test.

\section{Failure To Maintain The Benchmark}

Since the introduction of formalised enterprise bargaining in October 1991, awards have been relegated to the role of safety net, underpinning the shift to a decentralised wages system. Under both the Keating Government's Industrial Relations Reform Act 1993 and the Howard Government's Workplace Relations Act 1996, the Commission was required to periodically maintain the wages and conditions of the award safety net. In the Keating government's legislation, the power of the Commission to adjust the safety net was contained in section 90AA(2) which required the AIRC to '(a) ensure so far as it can, that the system of awards provides for secure, relevant and consistent wages and conditions of employment'. Section 88A(a) of the WR Act requires the Commission to ensure that 'wages and conditions of employment are protected by a system of enforceable awards established and maintained by the Commission'. Under related provisions in section $150 \mathrm{~A}$, of the IRRA, and $88 \mathrm{~b}(2)$ in the WR Act, the award safety net was and continues to be periodically adjusted by the Australian Industrial Relations Commission.

Whilst there have been regular adjustments to the safety net, it is important to note that these have not always been immediately reflected in award increases. Safety net adjustments have historically relied upon award parties to apply to vary their awards according to the safety net decision. Most importantly, however, adjustments to the safety net have never matched wage movements in collective and individual agreement making. This has resulted in a growing wages gap between wage growth in agreements and awards. Peetz (1998:535) has calculated that for employees reliant on the safety net, the first three 8 dollar per week adjustments were only worth about $1.5 \%$ each at a time when average increases under agreements were running between 4 to 5 per cent per annum. As the ACIRRT (2001) figure below suggests, this disparity has only grown since the introduction of the WR Act. 


\section{Figure 1. Movements in Wage Increases in Awards,}

Collective Agreements, AWAs and Executive Salaries, 1996-2000.

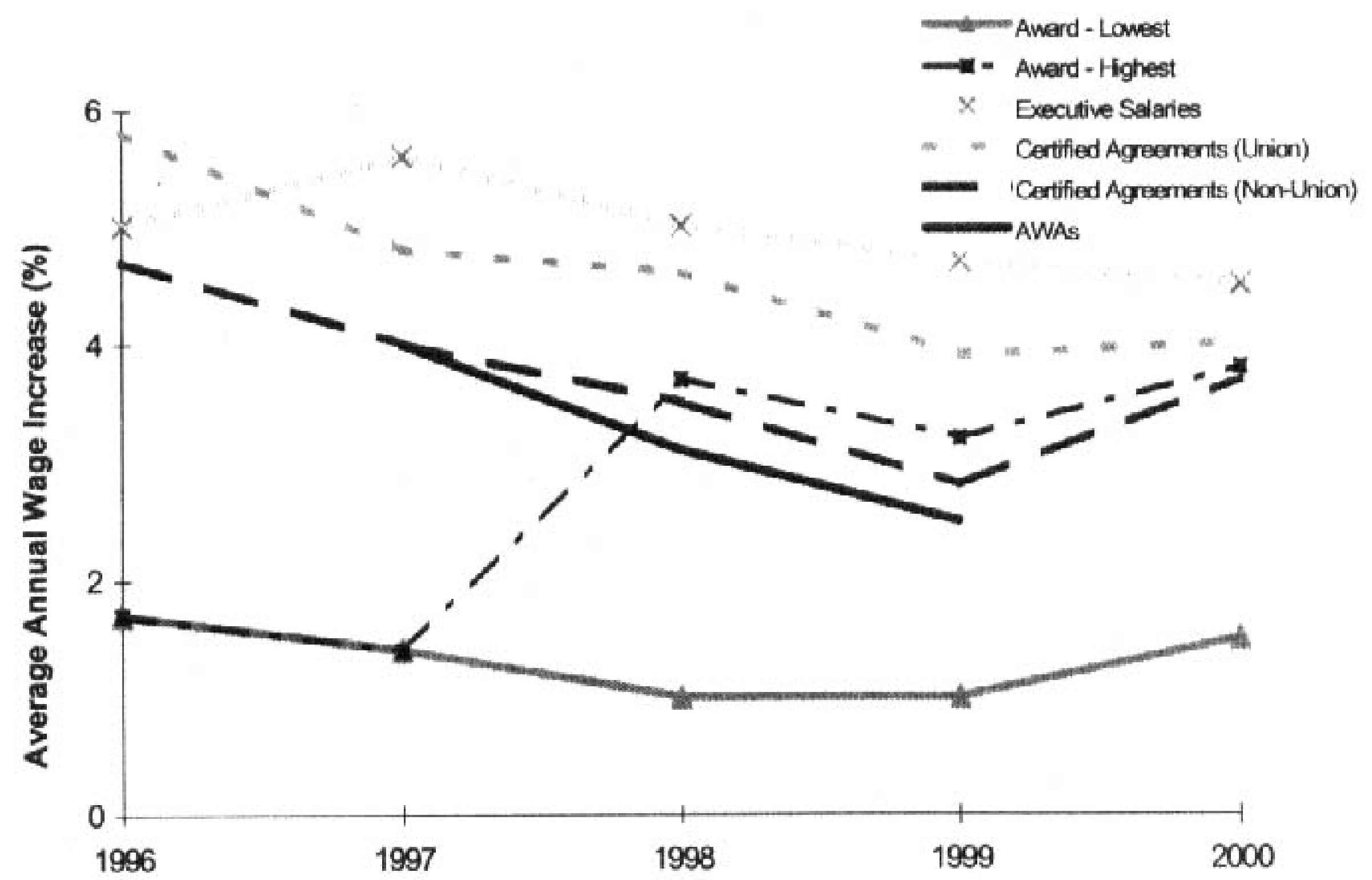

Source: ACIRRT (2001) ADAM Report, No. 28, March, ACIRRT, University of Sydney.

The figure shows that throughout the period 1996 to 2000, award wage rises have been consistently less than wage increases secured under certified agreements. The extent and pattern of disparity within and across industries is difficult to estimate, but it probably varies significantly, depending upon the nature of the industry and the extent of agreement coverage and bargaining experience.

This growing disparity should be of deep concern to policy makers if they remain true to the legislative intent of the NDT. The failure to properly maintain award wages not only creates a significant wage differential between those who bargain and those reliant on the safety net, but also creates 'wage space' for employers to potentially reduce wages over successive bargaining rounds. It could be argued that this disparity is to be expected given that bargaining outcomes frequently involve 'cashing in or out' or 'trading off' non-wage benefits and conditions. This argument, though, overlooks the considerable narrowing of award conditions through simplification and the capacity of management to drive change and intensify work without bargaining. Peetz (1998:537) for instance has cited findings from the 1995 and 1996 Department of Industrial Relations reports on enterprise bargaining to argue that the trend towards work intensification did not vary 
according to whether or not an agreement was in place. This suggests that the growing disparity between award and agreement wages cannot easily be defended.

\section{Wage Disparity as Bargaining Leverage?}

The disparity between agreements and awards also raises the spectre of some employers using this as an industrial tactic to further their claims at enterprise bargaining. Under the WR Act, it is now far easier for employers to seek to cancel enterprise agreements. In the recent BHP-CFMEU dispute (March, 2001), BHP have threatened to cancel existing enterprise agreements at their coal mines in Queensland. If successful, this would have the effect of transferring BHP employees back to the simplified Coal Mining Industry Consolidated Award 1997 and hence to wages and conditions that were much lower than what the employees had been receiving. Indeed, approximate estimates suggest that earnings for workers under BHP coal agreements would fall by approximately $\$ 10000$ to $\$ 20000$ per annum when they returned to the award ${ }^{6}$. This in effect, meant that BHP was able place considerable pressure on its workforce to accede to their demands.

In another case in the mining industry, workers at the Mt Thorley open cut coal mine were receiving an average annualised salary of $\$ 85,000$ when management terminated the enterprise agreement, effectively returning the workforce to industry award rates of pay. When a new certified agreement was negotiated, workers only recovered a little over half of the wages they had lost when the original certified agreement was terminated. The new agreement was worse than the original but better than the industry award, and so passed the NDT (Discussion, 12 March, 2001).

It must be argued that the NDT, as presently constructed, provides little protection against the possibility of employers cutting wages and conditions. Although the scope for employers reducing wages and conditions is narrowed by the application of the NDT, employers may still use new industrial instruments to reduce the wages and conditions in previous certified agreements and AWAs. In MUAv Burnie Port Corporation Pty Ltd (2000) FCA 1189, an applicant for a position with Burnie Port Corporation was offered employment on terms and conditions contained in an AWA which was said to be of less advantage than a pre-existing certified agreement. In this case, Justice Ryan warned:

It may be that in the future, if the designated award that provides the criteria for application of the "no disadvantage' test is not adjusted to reflect market trends evidenced by certified agreements and AWAs, the utility of the NDT in ensuring minimum standards will gradually diminish.

Clearly, the choice of bargaining instrument is not simply contingent upon the employer's ability to reduce wages and working conditions. However, the failure to maintain the award benchmark and the current design of the NDT make a 'cost minimisation' strategy a real and practical prospect. 


\section{What To Do About It?}

The last section explained how the NDT has frayed to the extent that its utility in ensuring workers under agreements are not disadvantaged must now be questioned. This steady deterioration of the test has serious implications for public policy, for unless community sentiment in Australia now accepts and approves of disadvantage in the bargaining process (beyond any natural power imbalance), the NDT needs to be overhauled to regain its original purpose. In this section we examine some of the means by which the effect of the NDT can be strengthened, balancing the equity and efficiency considerations of the various alternatives.

\section{(a) Reinstate non-allowable matters}

There is some evidence that Australian employers have benefited from gains in managerial prerogative, achieved through award simplification. The stripping away of non-allowable matters means the NDT may be applied against emaciated awards - as a sporting metaphor, agreements must now jump over a lower hurdle. One potential solution would be to reinstate non-allowable matters, thereby creating the opportunity for the parties to restore awards to not less than pre-1996 levels. It might also have the effect of reinstating clauses, such as preference provisions and right of entry, which supported union presence at the workplace. Union vigilance and scrutiny is a major check in the balancing of the NDT against proposed AWAs and collective agreements.

Winding back award simplification would be most unlikely given the neo-liberal policy agenda of the Coalition government. The ALP's industrial relations policy may seek to extend the current allowable matters, but given the advanced stage of award simplification, and that the process has been constitutionally validated by the High Court in Re CFMEU vs Pacific Coal 2000, a complete reversal of award simplification is unlikely. The resources needed by the industrial relations parties to resurrect awards fully back to their pre-simplification form would also be inhibiting.

\section{(b) Unions and/or the AIRC should improve award minima}

Another means by which the NDT may be strengthened would be for unions or the AIRC (on its own motion) to improve award minima to reflect general improvements in community living standards and the legitimate aspirations of the sellers in the wage/effort bargain. Certainly, the union movement devotes resources, especially the peak councils to increase the minimum wage and use test cases to enhance conditions. For example, in June 2001, the ACTU lodged an application to a full bench of the AIRC to insert a 'reasonable' hours clause into federal awards (Workplace Express: 14 May 2001). Similarly, the NSW Labor Council has announced its intention to insert into awards a general 'job security' clause to assist those in precarious employment (Field: 2001).

Competing objectives in the WR Act constrain this approach as a strategy to shore up the NDT. The AIRC is caught between the declaration that the role of awards is to form 
a safety net of minimum wages and conditions and its obligations pursuant to section $88 \mathrm{~b}(2)$ to ensure that awards are maintained. Outwardly, the wage disparity outlined earlier suggests the AIRC has erred more to the safety net objective, and that a perhaps less energetic drive to maintain awards has hampered the integrity of the NDT.

Whilst increasing award mimima would have the twin effects of securing the NDT and ensuring award workers do not slip further behind those under agreements, it would also be seen to be contrary to the strategy of encouraging enterprise bargaining. Both 'sides' of Australian politics advocate decentralised bargaining structures and have argued that small award safety net adjustments are desirable to provide the necessary incentive for parties to bargain (see Peetz, 1998:535). Moreover, it could be argued that award wages should not be lifted to a level comparative with agreements because agreements contain significant flexibilities, trade-offs and compromises which those under awards have not had to provide. The counter-argument to this position is that award simplification has resulted in the transfer of considerable flexibility to employers which ought to be compensated.

\section{(c) Legislate for minimum conditions}

Perhaps a more radical plan of protection, would be to precisely articulate in legislation those conditions of employment which could not be 'traded off' or 'cashed in or out' through the bargaining process. Legislative provisions could protect these 'nonnegotiables' and therefore limit the scope of bargaining to discourage negative cost minimisation strategies. It would also reduce much of the complexity associated with the current NDT. In certifying agreements, the AIRC's role would entail finding that statutory minima had not been breached or had been expressly improved upon. Ideally, the States would enact comparable harmonisation legislation, to overcome Commonwealth constitutional limitations, and ensure both the extension and parity of protected conditions throughout Australia. This would also have the effect of discouraging jurisdiction 'shopping'.

Whilst protecting certain minimum conditions of employment in this fashion may prove to be attractive, arguably, there are at least three distinct problems with this approach. Firstly, it would not address the steady erosion of award wages, nor the capacity of employers to use the growing disparity between award wages and agreements wages to their advantage. Secondly, there is little doubt that the length and breadth of the list of minimum conditions would become the subject of intense debate and, like the list of allowable award matters, could easily be cut or extended according to the 'whims' of whichever political party retains office. Finally, it would be difficult to account for different working conditions across industry in one set of legislative provisions. For instance, whilst four weeks annual leave is the norm in most industries, workers in the coal mining industry have historically enjoyed five weeks. Thus legislating for minimum conditions becomes a rather blunt instrument, incapable of accounting for significant differences in minimum conditions across industries. 


\section{(d) Permit industry-wide framework agreements}

Another alternative solution might be to provide legislative support to industry-wide framework agreements. These framework agreements could be negotiated at the industry level and establish minimum wages and conditions, specific to that industry. This would resolve the difficulties posed by simply legislating for minimum conditions, as basic wages and conditions would be tailored according to the industrial customs and traditions of each industry, in a manner not dissimilar to that originally provided by most awards. Under this approach, enterprise agreements would simply add to these framework or foundation agreements.

One question that would need to be resolved is the relationship between the industry award and these proposed framework agreements. Would these framework agreements supplant industry awards or merely extend industry awards? Moreover, there would also need to be consideration of how often these framework agreements would be negotiated and the means by which bargaining impasses could be resolved. Of course, the federal government's policy position on pattern bargaining would also have to significantly change. Despite these questions, this proposal appears to be meritorious and worthy of further consideration.

\section{(e) Apply the test against the last applicable industrial instrument}

The final option, in our discussion, would be to amend the WR Act so that the NDT is applied, not against a relevant or designated award, but rather the last applicable industrial instrument, being that legally-enforceable instrument underpinning the employees' wages and conditions before the current agreement was finalised. This may include common law employment contracts, awards, certified agreements and AWAs. In other words, the new benchmark would enable the AIRC to question 'Is this new agreement, inferior on balance, than the last applicable industrial instrument?'.

Such a mechanism would ensure that the benchmark for the NDT is not stationary or lagging, but rather would be automatically updated with each new industrial arrangement. It would also mean that the benchmark would be truly tailored to the previous employment conditions of workers. The global character of the present test could still be retained whilst the current complexity of comparison would be reduced, as differences between new agreements and the last industrial instrument are more likely to be clearly identifiable. In cases where employees are moving from informal and unregistered agreements to formal registered agreements, we would advocate providing the AIRC with the power to compare the proposed agreement with the existing wages and working conditions of these employees. Alternatively, the AIRC should be permitted to compare the agreement with another typical agreement from the same industry.

One argument against the inclusion of this new test is that it has the potential to render awards irrelevant. If awards are not the centrepiece of the NDT, the argument for their complete abolition will grow stronger. We would argue, however, that this should 
not be seen as the object or consequence of this new test. The phrase "last applicable industrial instrument' includes awards, and their abolition we submit, would remove the benchmark for a significant proportion of the workforce. Moreover, we would submit that the retention of awards as the only benchmark would mean that the potential for disadvantage would continue.

\section{Concluding Comments}

Throughout this paper, we have argued that the NDT has weakened such that workers can no longer have any faith in the utility of the test. In support of this contention, we have pointed to the deterioration of the test since 1991 which has occurred as a result of legislative change, the process of award simplification, the growing disparity between award wages and agreement outcomes and the complexity associated with application of the test. After reviewing alternative means by which to restore the effectiveness of the NDT, we have argued that changing the benchmark from awards to "the last applicable industrial instrument' presents the best and most feasible solution.

Undoubtedly, some will argue that the weakening of the NDT over the last decade is merely a reflection of the wishes of the community, expressed through their elected representatives. Yet the assurances made by both sides of Australian politics during the $1990 \mathrm{~s}$ suggest that this is not the case. Labor's promise that the NDT would safeguard worker's interests under enterprise bargaining, and the Howard Government's promise that 'no worker would be worse off' have not been kept. Even if the weakening of the test has not been the prime object of the Keating and Howard Governments, elements of their industrial relations reforms, especially award simplification under Howard, have had this effect.

Some may also argue that the weakening of the test simply provides additional labour market flexibility that should be viewed favourably. We would argue, though, that this sort of flexibility encourages a cost minimisation approach to labour management, inconsistent with the more desirable development of a high skill/high wage economy.

The NDT (along with the award safety net) has become a symbol of civility in Australian industrial relations. From time to time, both sides of politics, when pressed, have pointed to its presence as evidence that social justice principles, imbued in Australian cliches such as 'a fair go' and the notion of protecting 'the underdog', have been retained in the system. Yet we would argue that although the name and notion of the NDT have been retained, its capacity to limit the potential for disadvantage has become much diminished. The original intent of the test must be restored, if civility in Australian industrial relations is to be preserved.

\section{Endnotes}

1. The authors wish to thank the anonymous reviewers for their extensive and thought-provoking comments. Any remaining errors are the responsibility of the authors.

2. The authors wish to thank an anonymous reviewer for drawing this point to our attention. 
3. The retention of the NDT formed part of the compromise brokered between the Howard Government and the Australian Democrats to pass the WR Act in October 1996. When the original policy, to apply agreements against just seven minimum conditions, was announced, it was heavily criticised by the Labor Government. The then Minister for Industrial Relations, Laurie Brereton in a doorstep interview in September 1995 commented:

'It's hard to say how much worse off workers would be. But the reality is they've all got the potential to be worse off because without a comprehensive award underpinning every enterprise bargain, any worker can wake up and find that the totality of their conditions has been eroded. And that's the big difference. We've got a no disadvantage test but it's applied to a comprehensive award basis, so that you can't be worse off. They're talking about a Clayton's no disadvantage test, a phoney no disadvantage test. One that is compared not to a comprehensive award but to basic minima.'

4. Giudice, J.,Polites, S.D.P. and Redmond, C. Just Cuts (Canberra and Queanbeyan) Agreement, 2000-2003, October, 2000, Dec 1457/00 M, Print T3829

5. There are many decisions of the AIRC dealing with the application of the simplification principles to awards. See, for example, the decision of Harrison, C. in the Coal Mining Industry (Production \& Engineering) Consolidated Award 1997, 16 July 1999, Dec 474/99 N, Print R4611

6. Approximate figures calculated by comparing annualised salaries for ' $L 4$ ' $8.5 \mathrm{hr}$ and 12.5 hour production workers under the BHP Coal-CFMEU Saraji 1998 certified agreement with similar categories of employment in the Coal Mining Industry Consolidated Award of 1997.

\section{References}

Abbott, T. (2001) 'It's always unfinished business', The Australian Financial Review, 27 March, 2001

ACIRRT (1999) Australia at Work: Just Managing?, Prentice Hall, Sydney.

ACIRRT (2001) ADAM Report No. 28, March, ACIRRT, University of Sydney.

Alexander, R. and Lewer, J. (1996) Understanding Australian Industrial Relations, $4^{\text {th }}$ ed., Harcourt Brace, Marrickville.

Alexander, R. and Lewer, J. (1998) Understanding Australian Industrial Relations, $5^{\text {th }}$ ed., Harcourt Brace, Marrickville.

AMWU v Tweed Valley Fruit Processors Pty Ltd (1995) 61 IR 212

Australian Labour Law Reporter (2000) CCH Australia Ltd.

BHP Coal (2001) 'BHP Seeks to Terminate Queensland Coal Agreements', BHP News Release, 28 February.

Bray, M. and Waring, P. (1998) 'The Rhetoric and Reality of Bargaining Structures Under the Howard Government', Labour \& Industry, Vol. 9 No. 2, pp:61-79. 
Brereton, L. (1995) Press Release - Sydney doorstop interview, 14 September, Minister for Industrial Relations.

Creighton, B. and Stewart, A. (1990) Labour Law: an introduction, $I^{\text {st }}$ ed., The Federation Press, Sydney.

Creighton, B. and Stewart, A. (200(0) Labour Law: an introduction, $3^{\text {rd }}$ ed., The Federation Press, Sydney.

Dabscheck, B. (1995) The Struggle for Australian Industrial Relations, Oxford University Press, Melbourne.

Dee 1077/99 M Print R9030 Simmonds, C, Daviesway Pty Ltd Enterprise Agreement 1999.

Dec 1188/97 S Print P5472 Duncan, DP; Australian Workplace Agreements.

Dec 1276/97 M Print P6024, Whelan, C; Shop, Distributive and Allied Employees Association and Bunnings Building Supplies Pty Ltd (C No. 34875 of 1997).

Dec 1457/00 M Print T3829 Giudice, J, Polites, SDP and Redmond, C, Just Cuts (Canberra and Queanbeyan) Agreement, 2000-2003, October 2000.

Dec 1498/99 S Print S1 888 Duncan, DP; Australian Workplace Agreements.

Dec 1533/97 M Print P7500, Hospitality Award Test Case December 1997 (Matter no. H0008).

Dec 384/99 V Print R1999 Giudice, J; Ross, VP; McIntyre, VP; Macbean, SDP; Watson, SDP;

Gay, C and Cribb, C Safety Net Adjustment April 1999.

Dec 474/99 N Print R4611, Harrison, C, Coal Mining Industry (Production \& Engineering) Consolidated Award 1997, July 1999.

Dec 467/99 Ryan J, Maritime Union of Australia v. Burnic Port Corporation Pty Ltd (2000), FCA 1189.

Dec. 1197 Beaumont, Lee \& Gyles JJ Australasian Meat Industry Employees Union v Hamberger (2000) FCA.

DEWRSB (Department of Employment, Workplace Relations and Small Business) (2000) Safety Net Review - Wages 1999-2000, Joint Governments' Submissions, Commonwealth of Australia.

Department of Employment, Workplace Relations and Small Business and the Office of the Employment Advocate (2000) Agreement Making in Australia under the Workplace Relations Act 1998 and 1999, Commonwealth of Australia.

Discussion (12/03/01) Discussion held with a Manager employed at Hunter Valley No.1 mine, Newcastle.

Enterprise Flexibility Agreement Test Case (1995) 59 IR 430

Field, N. (2001) 'Unions: give casuals security', The Australian Financial Review, 11 May, 2001. Industrial Relations Act I988, No. 86 of 1988, Parliament of Australia.

MeCallum, R.C. (1994) 'The Imperfect Safety-Net: The Enforcement of Federal Awards and Agreements', in R. McCallum, G McGarry, and P. Ronfeldt (eds.) Employment Security, The Federation Press, Leichhardt.

Merlo, O. (2000) 'Flexibility and Stretching Rights: The No Disadvantage Test in Enterprise Bargaining', Australian.Journal of Labour Law, Vol. 13 No. 3, pp:207-235. 
Naughton, R. (1997) 'New Approaches to the Vetting of Agreements' in New Rights and Remedies for Individual Employees: Implications for Employers and Unions, Australian Centre for Industrial Relations Research and Training, Working Paper No. 48.

NSW Industrial Relations Commission: Application by Australian Business Limited for a new Pastoral Industry (State) Award, 13/03/2001

O'Neill, S. (1997) Award Simplification: progress report, Current Issues Briefs, Parliamentary Library, Canberra.

Peetz, D. (1998) 'The Safety Net, Bargaining and the Role of the Australian Industrial Relations Commission', The Journal of Industrial Relations, Vol.40 No.4, pp:533-553.

Re Pacific Coal Pty Limited; Ex parte Construction, Forestry, Mining and Energy Union (2000) HCA 34 ,

Reith, Hon P. (1997) Speech to the American Chamber of Commerce in Australia Luncheon, Sydney, Wednesday, 7 May.

Williams, P. (1997) The Victory, Allen and Unwin, Sydney.

Workplace Express (2001) OEA answers on AWAs, Justice Munno and staff harassment, 22 February 2001 .

Workplace Express (2001) ACTU begins reasonable hours bid, 14 May 2001.

Workplace Express (2001) IRC approves AWA paying \$7,000 less than award, 31 May 2001.

Workplace Relations Amendment (More Jobs, Better Pay) Bill 1999.

\section{Appendix A \\ The Evolution Of The No Disadvantage Test}

1988 - New Industrial Relations Act 1988 - Provided for s.115 Agreements subject to a Public Interest Test.

1991 (March) - Calls for Enterprise Bargaining Rejected by AIRC (decision labelled as 'vomit' and 'wickedly unfair' by Bill Kelty).

1991 (October) - Enterprise Bargaining Principle - Permits EB subject to a Public Interest Test and Commission's Wage Setting Principles.

1992 - Senator Cook introduces amendments to the IR Act 1988 - Provides for a No Disadvantage Test. Seemed to be line by line test but allowed reduction in terms if AIRC believed the agreement was in the public interest.

1993 - Keating Labor government introduces the Industrial Relations Reform Act - Altered definition of 'award' to exclude certified agreements and EFA's from NDT calculation. Minister Brereton also argues for broader balancing out of benefits and reductions in the NDT in his second reading speech. 
1995 Enterprise Flexibility Test Case-AIRC determines that NDT is not a line by line test but a global test.

1995 - Tweed Valley Case - On appeal suggests that long held community standards like sick leave cannot be reduced in the public interest.

1996 - Howard government's WROLA Bill introduced. Provides for 'No Less Favourable Test' to be applied against seven minimum conditions. This proposal blocked by Democrats.

1997 - Workplace Relations Act enacted. Legislation confirms EFA Test Case that NDT is a global test. Also permits agreements which fail the NDT to be certified if the AIRC believes it is not contrary to the public interest. Emphasis placed on assessing the overall agreement. Minister Reith argues in a speech in May 1997 that no single condition is not open to variation.

1997 -.Australian Workplace Agreements test case - DP Duncan claims that public interest considerations guided by objects of WRA. Certifies first 'failed' AWAs.

1998 (30 Junc) - Non-allowable matters in awards cannot be relied upon. Award Simplification dilutes the benchmark - results in a lower 'hurdle' for the NDT.

1999 - Howard government introduces the second wave industrial relations reforms (Workplace Relations Amendment (More Jobs, Better Pay) Bill 1999 (MOJO Bill). Reforms intended to reduce procedural requirements for meeting the NDT. Senate blocks the MOJO Bill.

\section{Appendix B \\ Allowable Matters}

Section 89A, Scope of industrial disputes, of the Workplace Relations Act specifies:

Industrial dispute normally limited to allowable award matters

(1) For the following purposes, an industrial dispute is taken to include only matters covered bysubsections (2) and (3):

(a) dealing with an industrial dispute by arbitration;

(b) preventing or settling an industrial dispute by making an award or order;

(c) maintaining the settlement of an industrial dispute by varying an award or order. 
Allowable award matters

(2) For the purposes of subsection (1) the matters are as follows:

(a) classifications of employees and skill-based career paths;

(b) ordinary time hours of work and the times within which they are performed, rest breaks, notice periods and variations to working hours;

(c) rates of pay generally (such as hourly rates and annual salaries), rates of pay for juniors, trainees or apprentices, and rates of pay for employees under the supported wage system;

(d) piece rates, tallies and bonuses;

(e) annual leave and leave loadings;

(f) long service leave;

(g) personal/carer's leave, including sick leave, family leave, bereavement leave, compassionate leave, cultural leave and other like forms of leave;

(h) parental leave, including maternity and adoption leave;

(i) public holidays;

(j) allowances;

(k) loadings for working overtime or for casual or shift work;

(1) penalty rates;

(m) redundancy pay;

(n) notice of termination;

(o) stand-down provisions;

(p) dispute settling procedures;

(q) jury service;

(r) type of employment, such as full-time employment, casual employment, regular part-time employment and shift work;

(s) superannuation;

(t) pay and conditions for outworkers, but only to the extent necessary to ensure that their overall pay and conditions of employment are fair and reasonable in comparison with the pay and conditions of employment specified in a relevant award or awards for employees who perform the same kind of work at an employer's business or commercial premises.

\section{PETER WARING \& JOHN LEWER, School of Management,} University of Newcastle 